\title{
Distribusi Genotipe dan Subtipe Virus Hepatitis B pada Penderita Hepatitis B Kronik di Pekanbaru
}

\author{
Arfianti, ${ }^{1}$ Andi Zainal, ${ }^{2}$ Fauzia Andrini, ${ }^{3}$ Rita Endriani ${ }^{3}$ \\ ${ }^{1}$ Bagian Biologi Kedokteran Fakultas Kedokteran Universitas Riau, \\ ${ }^{2}$ Bagian Ilmu Penyakit Dalam Fakultas Kedokteran Universitas Riau-RSUD Arifin Ahmad Pekanbaru, \\ ${ }^{3}$ Bagian Mikrobiologi Fakultas Kedokteran Universitas Riau
}

\begin{abstract}
Abstrak
Variasi genetik virus hepatitis B (VHB) dapat mempengaruhi manifestasi klinis, risiko karsinoma hepatoselular $(\mathrm{KH})$, dan respons terhadap terapi antiviral. Desain penelitian adalah analitik cross-sectional yang bertujuan untuk mengetahui apakah terdapat perbedaan distribusi genotipe dan subtipe VHB pada berbagai manifestasi klinis hepatitis B kronik di Pekanbaru. Sebanyak lima puluh dua serum penderita hepatitis B kronik di Pekanbaru diperoleh sejak bulan Maret sampai Agustus 2009 telah diperiksa pada penelitian ini. Analisis statistik menggunakan uji Fisher. Penentuan genotipe VHB dilakukan dengan membandingkan sikuens gen S pada penelitian ini dengan sikuens gen $\mathrm{S}$ yang telah dipublikasi pada GenBank. Hasil penelitian menunjukkan bahwa 31 (60\%) penderita terinfeksi oleh genotipe C dan $21(40 \%)$ oleh genotipe B. Berdasarkan manifestasi klinis, genotipe C merupakan genotipe yang paling banyak ditemukan pada donor darah (7/10 penderita) dan sirosis (7/10 penderita), sedangkan pada penderita hepatitis B kronik aktif dan KH ditemukan frekuensi genotipe B dan C yang hampir sama. Subtipe adr (60\%) merupakan subtipe yang paling banyak ditemukan, diikuti oleh subtipe adw (38\%) dan ayw (2\%). Berdasarkan hasil uji stastitik tidak ditemukan perbedaan bermakna distribusi genotipe dan subtipe pada berbagai manifestasi klinis infeksi VHB. Namun, genotipe C (8/9 penderita) merupakan genotipe VHB yang paling banyak ditemukan pada penderita KH dengan sirosis, sedangkan genotipe B (8/11 penderita) merupakan genotipe VHB yang paling banyak menginfeksi penderita KH tanpa sirosis $(\mathrm{p}=0,01)$. Simpulan, genotipe VHB mungkin berhubungan dengan patogenesis karsinoma hepatoselular dengan sirosis dan tanpa sirosis. [MKB. 2011;43(3):105-11].
\end{abstract}

Kata kunci: Genotipe, hepatitis B kronik, karsinoma hepatoselular, sirosis, subtipe

\section{Distribution of Hepatitis B Virus Genotypes and Subtypes Among Chronic Hepatitis B Patients in Pekanbaru}

\begin{abstract}
Genetic variance of hepatitis B virus (HBV) may influence the clinical manifestation, development of hepatocellular carcinoma (HCC), and response to antiviral treatment. This was analytic cross-sectional study which aimed to investigate the distribution of HBV genotypes and subtypes among different clinical status of chronic hepatitis B in Pekanbaru. A total of fifty-two of sera from chronic hepatitis B patients in Pekanbaru was collected from March to August 2009. Statistical analysis was performed by using Fisher test. HBV genotypes were examined based on homology of S gene from this study with those of GenBank database. Of these subjects, 31 (60\%) and 21 (40\%) were infected by genotype $\mathrm{C}$ and $\mathrm{B}$, respectively. Based on clinical manifestation, genotype $\mathrm{C}$ was predominantly found among HBsAg-positive blood donors (7/10 patients) and liver cirrhosis (7/10 patients), whereas genotype $\mathrm{B}$ and $\mathrm{C}$ were comparable among chronic hepatitis B active and hepatocellular carcinoma patients. Subtype adr $(60 \%)$ was the most prevalent, followed by subtype adw (38\%) and subtype ayw (2\%). There were no significant difference in the distribution of HBV genotypes and subtypes among diverse clinical manifestation of HBV infection. However, genotype $\mathrm{C}$ was predominantly detected among cirrhotic-HCC (8/9 patients), while genotype $B$ was mostly identified among non cirrhotic-HCC (8/11 patients) $(p=0.01)$. In conclusion, HBV genotype may be associated with the pathogenesis of cirrhotic and noncirrhotic-HCC. [MKB. 2011;43(3):105-11].
\end{abstract}

Key words: Chronic hepatitis B, genotype, hepatocellular carcinoma, liver cirrhosis, subtype

Korespondensi: Arfianti, dr., M.Biomed., M.Sc, Bagian Biologi Kedokteran Fakultas Kedokteran Universitas Riau, jalan Diponegoro 1 Pekanbaru 28111,mobile 081371678530,e-mail: evi_anti@yahoo.com 


\section{Pendahuluan}

Infeksi virus hepatitis B (VHB) beserta komplikasinya masih menjadi masalah kesehatan di seluruh dunia. Sejak pertama kali ditemukan pada tahun 1966, VHB telah menginfeksi lebih dari 2 miliar orang di dunia, sebanyak 350 juta di antaranya kemudian berlanjut menjadi penderita hepatitis B kronik. Berdasarkan penelitian terdahulu, 15-40\% penderita hepatitis B kronik berisiko menderita sirosis hati dan karsinoma hepatoselular. ${ }^{1}$ Sesuai dengan konsensus hasil pertemuan Core Working Party for Asia-Pasific, Indonesia digolongkan dalam negara dengan endemisitas rendah sampai tinggi dengan prevalensi karier $\mathrm{HBsAg}$ sebesar $4,0-20,3 \% .^{2}$

Berdasarkan variasi susunan genom VHB, saat ini telah teridentifikasi 8 genotipe VHB, yaitu genotipe $\mathrm{A}-\mathrm{H} \cdot{ }^{3,4}$ Selain genotipe, juga telah diketahui ada 4 subtipe utama VHB, yaitu adw, ayw, adr, dan ayr berdasarkan determinan antigenik HBsAg. ${ }^{5}$ Penelitian epidemiologi menunjukkan adanya distribusi spesifik genotipe dan subtipe VHB, baik secara geografis maupun etnis. Genotipe A merupakan genotipe yang paling banyak ditemukan di negara Eropa bagian Utara dan Tengah, di samping juga sering ditemukan di Amerika bagian Utara dan Afrika Subsahara. Genotipe B dan C merupakan genotipe utama di Asia. Genotipe D terdistribusi secara luas, tetapi lebih sering terdeteksi di negara Mediteranea, sedangkan genotipe E terutama ditemukan di negara-negara Afrika bagian Barat. Genotipe F merupakan genotipe yang khusus ditemukan pada populasi Aborigin di Australia. Genotipe $\mathrm{G}$ dilaporkan telah ditemukan di Amerika Serikat dan Perancis. ${ }^{4}$

Meskipun belum sepenuhnya terbukti, beberapa penelitian terdahulu menunjukkan pengaruh genotipe VHB pada manifestasi klinis dan perjalanan penyakit infeksi VHB serta respons terhadap terapi antiviral. Penelitian yang dilakukan di Jepang dan Taiwan melaporkan bahwa $\mathrm{HBeAg}$ positif dan rendahnya angka serokonversi HBeAg lebih sering ditemukan pada penderita hepatitis B kronik yang terinfeksi genotipe C dibandingkan dengan genotipe B. ${ }^{6}$ Selain itu, konsentrasi DNA VHB lebih tinggi pada penderita yang terinfeksi oleh genotipe C. ${ }^{7}$ Di samping genotipe, variasi genetik VHB lainnya juga diketahui mempengaruhi perjalanan penyakit hepatitis B kronik. ${ }^{8}$ Salah satu variasi genetik ini adalah mutasi ganda basal core promoter (BCP) pada nukleotida (nt) 1762 (A-T) dan nt 1764 (GA) yang dilaporkan lebih sering ditemukan pada penderita yang terinfeksi genotipe $\mathrm{C}$ dibandingkan dengan genotipe $\mathrm{B}$. Hasil penelitian ini secara bersama-sama memperlihatkan bahwa genotipe C merupakan VHB yang lebih agresif, sehingga menyebabkan penyakit hati yang lebih progresif dengan prognosis yang lebih jelek dibandingkan dengan genotipe B. Dugaan ini diperkuat penelitian yang menunjukkan adanya hubungan antara genotipe VHB dan risiko karsinoma hepatoselular (KH). ${ }^{8,9}$ Studi cross-sectional yang dilakukan di Taiwan melaporkan bahwa genotipe $\mathrm{C}$ lebih sering ditemukan pada penderita $\mathrm{KH}$ yang berusia lebih dari 50 tahun dibandingkan dengan karier HBsAg asimtomatik. Sebaliknya, genotipe B lebih banyak terdeteksi pada penderita KH yang berusia di bawah 50 tahun. ${ }^{10}$ Dugaan ini didukung oleh penelitian kohort yang memperlihatkan individu yang terinfeksi oleh VHB genotipe C mempunyai risiko 5 kali lebih besar dibandingkan dengan genotipe VHB lainnya ${ }^{9}$ dan 2 kali lebih besar jika dibandingkan genotipe B untuk menderita $\mathrm{KH}^{8}{ }^{8}$ Lebih kurang $75 \%$ penderita hepatitis B kronik dilaporkan berasal dari negara di Asia, sehingga perlu dilakukan penelitian lebih mendalam pada populasi ini untuk memperoleh gambaran lebih jelas pengaruh variasi genetik pada perjalanan penyakit infeksi VHB. ${ }^{11}$

Sampai saat ini penelitian genotipe dan subtipe VHB di Indonesia masih terbatas. Penelitian yang dilakukan Sastrosoewignjo dkk. seperti dikutip Nugrahaputra dkk., ${ }^{2}$ terdapat 3 macam genotipe di Indonesia, yaitu B (subtipe adw dan ayw), C (subtipe adw, adr, dan ayr), dan D (subtipe ayw). Penelitian yang dilakukan pada donor darah di Jayapura menyatakan bahwa ditemukan genotipe C $(85,2 \%)$, B $(7,4 \%)$, dan C $(7,4 \%)$, sedangkan subtipe adr merupakan subtipe yang dominan dan diikuti dengan subtipe adw2 dan ayw2.

Penelitian ini bertujuan untuk mengetahui apakah terdapat perbedaan distribusi genotipe dan subtipe VHB pada berbagai manifestasi klinis hepatitis B kronik di Pekanbaru. Penelitian ini diharapkan dapat menambah informasi mengenai distribusi epidemiologi molekuler VHB di Indonesia serta pengaruh genotipe pada perjalanan penyakit hepatitis B kronik. Hasil penelitian ini juga dapat dimanfaatkan untuk mengembangkan langkah-langkah terapi yang lebih efektif dan efisien untuk mencegah perkembangan penyakit hepatitis B yang lebih lanjut.

\section{Metode}

Penelitian ini merupakan penelitian analitik dengan desain cross-sectional. Subjek penelitian terdiri atas penderita hepatitis B kronik asimtomatik, yaitu donor darah dengan HBsAg positif yang diperoleh dari Palang Merah Indonesia Cabang Pekanbaru dengan metode consecutive sampling, sedangkan penderita hepatitis B kronik aktif, sirosis hati, dan $\mathrm{KH}$ diseleksi pada salah satu praktik dokter spesialis 
penyakit dalam di Pekanbaru. Sampel berupa darah penderita hepatitis B kronik diperoleh sejak bulan Maret sampai bulan Agustus 2009. Diagnosis hepatitis B kronik ditegakkan berdasarkan HBsAg positif lebih dari 6 bulan. Penderita sirosis hati dan $\mathrm{KH}$ didiagnosis berdasarkan anamnesis, pemeriksaan fisis, USG abdomen, dan pemeriksaan laboratorium seperti tes fungsi hati, alfa-fetoprotein, dan alkali fosfatase. Deteksi HBsAg dilakukan dengan metode reverse passive hemagglutination assay (RPHA) menggunakan kit yang beredar di pasaran. Tes fungsi hati seperti SGPT dan SGOT dilakukan dengan metode UV-optimized standard. Semua subjek penelitian terlebih dahulu menandatangani kesediannya (informed consent) sebelum dilibatkan dalam penelitian ini. Sampel darah yang diperoleh kemudian disentrifugasi untuk memperoleh serum yang selanjutnya disimpan pada suhu $-20^{\circ} \mathrm{C}$ sampai pemeriksaan lebih lanjut.

Isolasi DNA VHB dari serum menggunakan DNA-zol (Invitrogen, California, USA). Mulamula $100 \mu \mathrm{L}$ serum dimasukkan dalam 1.000 $\mu \mathrm{L}$ DNA-zol, lalu divorteks dengan kecepatan penuh selama 2 menit. Selanjutnya ditambahkan isopropanolol dan disentrifugasi pada kecepatan $13.000 \mathrm{rpm}$ selama 6 menit. Supernatan yang ada dibuang dan DNA dipresipitasi dengan menambahkan etanol 75\%. Presipitat DNA VHB dilarutkan kembali dalam $50 \mu \mathrm{L}$ akuabides.

Amplifikasi fragmen gen S genom VHB dilakukan dengan menggunakan metode nested polymerase chain reaction (nested $\mathrm{PCR}$ ). Pada PCR putaran pertama digunakan primer forward P7 (5'-GTG GTG GAC TTC TCT CAA TTT TC-3'; posisi 256-278) dan primer reverse $\mathrm{P} 8$ (5'CGG TAT AAA GGG ACT CAG GAT-3'; posisi 796-776) yang akan menghasilkan fragmen DNA berukuran 540 base pairs (bp). Jika tahap pertama amplifikasi PCR negatif, maka dilakukan PCR tahap kedua dengan primer forward HBS1 (5'CAA GGT ATG TTG CCC GTT TG-3'; posisi 455-474) dan primer reverse HBS2 (5'-AAA GCC CTG CGA ACC ACT GA-3'; posisi 713694) yang akan menghasilkan fragmen DNA yang berukuran $258 \mathrm{bp} .^{2}$

Amplifikasi dilakukan dengan mesin PCR sprint (Thermo, USA) dalam $50 \mu \mathrm{L}$ volume reaksi, dengan kondisi PCR yang telah dioptimasi dengan keseluruhan amplifikasi sebanyak 35 siklus yang terdiri atas tahap denaturasi pada suhu $95^{\circ} \mathrm{C}$ selama 1 menit, tahap annealing pada suhu $50^{\circ} \mathrm{C}$ selama 50 detik dan tahap ekstensi pada suhu $72^{\circ} \mathrm{C}$ selama 1 menit, serta diakhiri dengan tahap ekstensi akhir pada suhu $72^{\circ} \mathrm{C}$ selama 5 menit.

Reaksi PCR menggunakan PCR core system (Promega, Madison, WI, USA) terdiri atas $20 \mathrm{mM}$ TrisHCl (pH 8,4), $50 \mathrm{mM} \mathrm{KCL}, 1,5 \mathrm{mM} \mathrm{MgCl} 2$, 2,5 unit Taq DNA polimerase, $0,5 \mu \mathrm{M}$ masing- masing primer, $0,2 \mu \mathrm{M}$ masing-masing dNTPs (dATP, dTTP, dCTP, dGTP) dan $10 \mu \mathrm{L}$ cetakan DNA. Deteksi produk PCR dilakukan dengan elektroforesis pada gel agarosa $2 \%$ yang diwarnai dengan etidium bromida untuk selanjutnya diamati di bawah iluminator sinar ultraviolet.

Selanjutnya dilakukan sekuensing produk PCR menggunakan metode dye-labelled terminators menggunakan mesin ABI prism 377A applied biosystems. Analisis genotipe VHB dilakukan dengan cara membandingkan sikuens gen $\mathrm{S}$ yang diperoleh pada penelitian ini dengan gen S yang telah dipublikasi pada GenBank menggunakan program BLAST. Program ini akan menghitung homologi dari sekuens yang dibandingkan. Genotipe ditentukan berdasarkan homologi pada gen S yang lebih dari $96 \%$. Susunan nukleotida gen S kemudian dikonversi menjadi susunan asam amino. Subtipe VHB ditentukan berdasarkan analisis residu asam amino pada posisi 122 dan 160. Untuk mengetahui apakah terdapat perbedaan distribusi genotipe dan subtipe VHB pada berbagai manifestasi klinis hepatitis B kronik dilakukan uji Fisher dan dianggap bermakna jika $\mathrm{p}<0,05$.

\section{Hasil}

Selama periode penelitian telah dilakukan penentuan genotipe dan subtipe pada 52 orang penderita hepatitis B kronik yang terdiri atas 10 orang donor darah dengan HBsAg positif, 12 orang penderita hepatitis B kronik aktif, 10 orang penderita sirosis, dan 20 orang penderita $\mathrm{KH}$ (Tabel 1). Usia rata-rata subjek penelitian $45,5 \pm 12,3$ tahun. Usia rata-rata kelompok donor darah lebih muda (26 \pm 6.7 tahun) dibandingkan dengan ketiga kelompok lainnya, yaitu penderita hepatitis B kronik aktif $(43,3 \pm 11,4$ tahun), sirosis $(52,9 \pm 11,3$ tahun), dan KH (48,2 $\pm 8,7$ tahun). Demikian pula usia rata-rata kelompok penderita $\mathrm{KH}$ tanpa sirosis lebih muda dibandingkan dengan usia rata-rata kelompok penderita $\mathrm{KH}$ dengan sirosis $(46,6 \pm 9,7$ tahun vs $50,6 \pm 7,3$ tahun). Sebagian besar subjek penelitian berjenis kelamin laki-laki (90\%).

Berdasarkan homologi sekuens gen S, hanya ada dua genotipe VHB yang teridentifikasi pada penelitian ini, yaitu genotipe B dan C (Tabel 2). Genotipe $\mathrm{C}$ merupakan genotipe yang dominan $(60 \%)$, sedangkan selebihnya adalah genotipe B $(40 \%)$. Subtipe VHB yang terdeteksi adalah adr $(60 \%)$ diikuti oleh adw $(38 \%)$ dan ayw $(2 \%)$, sedangkan subtipe ayr tidak ditemukan pada penelitian ini (Tabel 3). Berdasarkan genotipenya, subtipe adr merupakan subtipe yang ditemukan pada seluruh genotipe C. Subtipe adw adalah subtipe utama pada genotipe B (20/21 penderita) 
Tabel 1 Karakteristik Subjek Penelitian

\begin{tabular}{|c|c|c|c|c|c|c|c|}
\hline \multirow[b]{2}{*}{ Karakteristik } & \multirow{2}{*}{$\begin{array}{c}\text { Donor } \\
\text { Darah } \\
\text { dengan } \\
\text { HBsAg } \\
\text { Positif } \\
(n=10)\end{array}$} & \multirow[b]{2}{*}{$\begin{array}{l}\text { Hepatitis B } \\
\text { Kronik Aktif } \\
\quad(n=12)\end{array}$} & \multirow[b]{2}{*}{$\begin{array}{l}\text { Sirosis } \\
(n=10)\end{array}$} & \multicolumn{3}{|c|}{ KH } & \multirow[b]{2}{*}{$\begin{array}{c}\text { Total } \\
(n=52)\end{array}$} \\
\hline & & & & $\begin{array}{c}\text { Dengan } \\
\text { Sirosis } \\
(n=9)\end{array}$ & $\begin{array}{l}\text { Tanpa } \\
\text { Sirosis } \\
(n=11)\end{array}$ & $\begin{array}{c}\text { Total KH } \\
(\mathbf{n}=\mathbf{2 0})\end{array}$ & \\
\hline $\begin{array}{l}\text { Usia (rata- } \\
\text { rata } \pm \text { SD, } \\
\text { tahun) }\end{array}$ & $26 \pm 6,7$ & $43,3 \pm 11,4$ & $52,9 \pm 11,3$ & $50,6 \pm 7,3$ & $46,6 \pm 9,7$ & $48.2 \pm 8,7$ & $45,5 \pm 12,3$ \\
\hline $\begin{array}{l}\text { Jenis kelamin } \\
\text { Laki-laki } \\
\text { Perempuan }\end{array}$ & $\begin{array}{c}10 / 10 \\
0 / 10\end{array}$ & $\begin{array}{l}11 / 12 \\
1 / 12\end{array}$ & $\begin{array}{l}8 / 10 \\
2 / 10\end{array}$ & $\begin{array}{l}8 / 9 \\
1 / 9\end{array}$ & $\begin{array}{c}10 / 11 \\
1 / 11\end{array}$ & $\begin{array}{c}9 / 20 \\
11 / 20\end{array}$ & $\begin{array}{l}90 \% \\
10 \%\end{array}$ \\
\hline
\end{tabular}

dan pada semua penderita yang terinfeksi genotipe B memiliki subtipe ayw (1/21 penderita).

Berdasarkan manifestasi klinis, genotipe $\mathrm{C}$ terdapat pada 7/10 genotipe VHB kelompok donor darah dan sirosis, sedangkan pada kelompok penderita hepatitis B kronik aktif dan $\mathrm{KH}$, didapatkan frekuensi genotipe $\mathrm{B}$ dan genotipe $\mathrm{C}$ yang tidak jauh berbeda. Pada kelompok penderita $\mathrm{KH}$, genotipe $\mathrm{B}$ merupakan genotipe yang paling banyak ditemukan pada penderita $\mathrm{KH}$ tanpa sirosis (8/11 penderita), sebaliknya genotipe $\mathrm{C}$ lebih sering menginfeksi penderita $\mathrm{KH}$ dengan sirosis (8/9 penderita) tetapi berdasarkan hasil uji statistik, tidak ditemukan perbedaan distribusi genotipe yang bermakna antara donor darah, hepatitis $\mathrm{B}$ kronik aktif, sirosis, dan KH (Tabel 4). Perbedaan yang bermakna hanya ditemukan antara $\mathrm{KH}$ dengan sirosis dan $\mathrm{KH}$ tanpa sirosis; genotipe $\mathrm{B}$ lebih sering ditemukan pada kelompok KH tanpa sirosis dibandingkan $\mathrm{KH}$ dengan sirosis (8/11 vs $1 / 9$ penderita, $\mathrm{p}=0,01$ ), sebaliknya genotipe $\mathrm{C}$ lebih sering menginfeksi kelompok $\mathrm{KH}$ dengan sirosis dibandingkan dengan $\mathrm{KH}$ tanpa sirosis (8/9 vs $3 / 11$ penderita, $\mathrm{p}=0.01$ ).

\section{Pembahasan}

Sesuai dengan hasil penelitian sebelumnya, ${ }^{12}$ ada dua genotipe VHB yang berhasil dideteksi pada penderita hepatitis B kronik di Pekanbaru.
Genotipe $\mathrm{C}$ merupakan genotipe yang dominan $(60 \%)$, sedangkan selebihnya adalah genotipe B $(40 \%)$. Hasil penelitian ini dapat dijadikan data pelengkap distribusi epidemiologi molekuler VHB di Indonesia yang telah ada sebelumnya. ${ }^{12-14}$ Penelitian terbaru yang dilakukan Mulyanto dkk. ${ }^{13}$ melaporkan bahwa genotipe $\mathrm{B}$ dan $\mathrm{C}$ juga merupakan genotipe VHB yang dominan ditemukan di Indonesia. Penelitian yang melibatkan 899 subjek penelitian berasal dari 28 kota yang ada di Indonesia tersebut melaporkan bahwa genotipe $\mathrm{B}$ sebagai genotipe yang dominan $(66 \%)$, diikuti oleh genotipe C $(26 \%)$, genotipe D $(7 \%)$, dan genotipe A $(0,8 \%)$. Genotipe C merupakan genotipe yang banyak ditemukan di Sangihe Talaud, Maluku Utara, dan Papua, sedangkan genotipe B umum ditemukan di Pulau Sumatera, Jawa, Bali, Sumba, dan Flores. Genotipe D merupakan genotipe VHB yang dominan ditemukan di Maluku Selatan, sedangkan genotipe A hanya ditemukan di Kalimantan Timur dan Kupang. Untuk pulau Sumatera terdapat pengecualian oleh karena di kota Padang yang paling banyak ditemukan adalah genotipe C. ${ }^{13,15}$ Pekanbaru sebagai kota yang memiliki kedekatan geografis dan etnis dengan kota Padang ternyata memperlihatkan pola distribusi genotipe VHB yang hampir sama, yaitu didominasi oleh genotipe C. Data ini semakin memperkuat dugaan bahwa geografik dan etnik sebagai salah satu faktor yang mempengaruhi distribusi varian genetik VHB. ${ }^{4}$

Tabel 2 Distribusi Genotipe VHB pada Penderita Hepatitis B Kronik

\begin{tabular}{|c|c|c|c|c|c|c|c|}
\hline \multirow[b]{2}{*}{$\begin{array}{c}\text { Genotipe } \\
\text { VHB }\end{array}$} & \multirow{2}{*}{$\begin{array}{c}\text { Donor } \\
\text { Darah } \\
\text { dengan } \\
\text { HBsAg } \\
\text { Positif } \\
(n=10)\end{array}$} & \multirow[b]{2}{*}{$\begin{array}{c}\text { Hepatitis } \\
\text { B Kronik } \\
\text { Aktif } \\
(\mathbf{n}=12)\end{array}$} & \multirow[b]{2}{*}{$\begin{array}{l}\text { Sirosis } \\
(n=10)\end{array}$} & \multicolumn{3}{|c|}{ KH } & \multirow[b]{2}{*}{$\begin{array}{c}\text { Total } \\
(n=52)\end{array}$} \\
\hline & & & & $\begin{array}{c}\text { Dengan } \\
\text { Sirosis } \\
(n=9)\end{array}$ & $\begin{array}{c}\text { Tanpa } \\
\text { Sirosis } \\
(n=11)\end{array}$ & $\begin{array}{c}\text { Total } \\
(\mathbf{n}=\mathbf{2 0})\end{array}$ & \\
\hline B & $3 / 10$ & $6 / 12$ & $3 / 10$ & $1 / 9$ & $8 / 11$ & $9 / 20$ & $40 \%$ \\
\hline C & $7 / 10$ & $6 / 12$ & $7 / 10$ & $8 / 9$ & $3 / 11$ & $11 / 20$ & $60 \%$ \\
\hline
\end{tabular}


Tabel 3 Distribusi Subtipe berdasarkan Genotipe HBV

\begin{tabular}{cccc}
\hline \multirow{2}{*}{ Subtipe VHB } & \multicolumn{3}{c}{ Genotipe VHB } \\
\cline { 2 - 4 } & $\begin{array}{c}\text { B } \\
(\mathbf{n = 2 1 )}\end{array}$ & $\begin{array}{c}\text { Cotal } \\
(\mathbf{n = 3 1 )}\end{array}$ \\
\hline adw & $20 / 21$ & $0 / 31$ & $38 \%$ \\
adr & $0 / 21$ & $31 / 31$ & $60 \%$ \\
ayw & $1 / 21$ & $0 / 31$ & $2 \%$ \\
ayr & $0 / 21$ & $0 / 31$ & $0 \%$ \\
\hline
\end{tabular}

Banyaknya penduduk kota Pekanbaru yang merupakan suku Minang yang juga merupakan suku asli di kota Padang, ditambah dengan mobilitas penduduk dari dan ke kota Padang yang sangat tinggi memungkinkan terjadinya kesamaan distribusi genotipe VHB antara kedua kota ini.

Saat ini terdapat 4 subtipe utama HBsAg, yaitu adw, adr, ayw, dan ayr berdasarkan susunan asam amino pada posisi 122 dan 160 gen S. Varian HBSAg ini juga memiliki distribusi geografik dan etnik yang berbeda. Distribusi subtipe VHB yang ditemukan pada penelitian ini sesuai dengan penelitian terdahulu, ${ }^{12,13}$ yaitu adr sebagai subtipe yang paling banyak ditemukan sesuai dengan subtipe dominan di kota Padang. Subtipe adw merupakan subtipe yang banyak ditemukan di Indonesia bagian Barat, kecuali Padang. Subtipe ayw paling sering ditemukan di Sulawesi, Maluku Selatan, Lombok, Sumbawa, Sumba, Flores, dan Timor, sedangkan subtipe adr merupakan subtipe yang dominan ditemukan di Papua. Subtipe ayr sangat jarang ditemukan di Indonesia (1\%) dan dilaporkan berasal dari Jakarta, Manado, dan Jayapura. ${ }^{13}$ Pada penelitian ini juga terlihat adanya distribusi subtipe VHB yang spesifik berdasarkan genotipenya, ternyata adw merupakan subtipe yang ditemukan pada hampir seluruh genotipe B (20/21 penderita), hanya 1 genotipe $\mathrm{B}$ yang mempunyai subtipe ayw (1/21 penderita). Sebaliknya, subtipe adr merupakan subtipe spesifik pada genotipe $\mathrm{C}$
(31/31 penderita).

Meskipun masih belum terdapat kesepakatan di antara para ahli, beberapa penelitian menunjukkan adanya pengaruh genotipe VHB pada manifestasi klinis infeksi hepatitis B. Penelitian yang telah dilakukan menunjukkan bahwa genotipe $\mathrm{C}$ berhubungan dengan manifestasi klinis hepatitis B yang lebih berat. Penelitian tentang pengaruh genotipe VHB pada penderita hepatitis B kronik di Indonesia masih sangat terbatas. Pada penelitian ini, genotipe $\mathrm{C}$ merupakan genotipe yang paling banyak ditemukan pada kelompok donor darah dan sirosis, sedangkan frekuensi genotipe B dan C tidak jauh berbeda pada kelompok penderita hepatitis B kronik aktif dan KH. Sejauh pengetahuan penulis, saat ini hanya ada tiga penelitian sejenis yang pernah dilaporkan di Indonesia. Pada satu penelitian terbaru yang dilakukan Utama dkk. ${ }^{11}$ didapatkan distribusi genotipe dan subtipe VHB yang berbeda dengan yang dilaporkan pada penelitian ini, mereka melaporkan genotipe B sebanyak 75\%, genotipe yang ditemukan pada berbagai manifestasi klinis infeksi VHB seperti hepatitis kronik, sirosis, dan KH. Penelitian yang dilakukan Lusida dkk. ${ }^{16}$ dilaporkan bahwa genotipe B sebagai satu-satunya genotipe pada penderita hepatitis B kronik dan penderita hemodialisis di Surabaya. Perbedaan hasil ini mungkin disebabkan adanya perbedaan asal subjek penelitian, subjek penelitian kali

Tabel 4 Perbandingan Distribusi Genotipe VHB pada Berbagai Manifestasi Klinis Hepatitis B Kronik

\begin{tabular}{lc}
\hline \multicolumn{1}{c}{ Analisis 2 kelompok } & $\mathbf{p}$ \\
\hline Donor darah dengan HBsAg positif vs Hepatitis B kronik aktif & NS \\
Donor darah dengan HBsAg positif vs Sirosis & NS \\
Donor darah dengan HBsAg positif vs KH dengan sirosis & NS \\
Donor darah dengan HBsAg positif vs KH tanpa sirosis & NS \\
Donor darah dengan HBsAg positif vs KH & NS \\
Hepatitis B kronik aktif vs Sirosis & NS \\
Hepatitis B kronik aktif vs KH dengan sirosis & NS \\
Hepatitis B kronik aktif vs KH tanpa sirosis & NS \\
Hepatitis B kronik aktif vs KH & NS \\
Sirosis vs KH dengan sirosis & NS \\
Sirosis vs KH tanpa sirosis & NS \\
Sirosis vs KH & 0,01 \\
KH dengan sirosis vs KH tanpa sirosis &
\end{tabular}

Keterangan: NS: non significant 
ini berasal dari daerah yang didominasi oleh genotipe $\mathrm{C}$, sedangkan subjek pada penelitian Utama dkk. ${ }^{11}$ dan Lusida dkk. ${ }^{16}$ berasal dari daerah yang didominasi genotipe B. Hal ini didukung oleh hasil penelitian yang dilaporkan dari kota Padang sebagai daerah yang memiliki kedekatan geografik dan etnik dengan kota Pekanbaru, bahwa genotipe C merupakan $65 \%$ genotipe VHB yang ditemukan pada penderita hepatitis B kronik. ${ }^{15}$ Selain itu, pada penelitian tersebut juga diketahui bahwa subtipe adr adalah subtipe HBsAg yang paling banyak ditemukan, yaitu sebesar $67,6 \%$, lebih kurang hampir sama dengan yang ditemukan pada penelitian ini, yaitu $60 \%$.

Hasil uji statistik menunjukkan tidak terdapat perbedaan distribusi genotipe yang bermakna pada berbagai manifestasi klinis hepatitis B kronik. Utama dkk. ${ }^{11}$ juga tidak menemukan perbedaan distribusi genotipe antar berbagai manifestasi klinis hepatitis B kronik. Pada penelitian kali ini genotipe $\mathrm{C}$ lebih sering ditemukan pada penderita $\mathrm{KH}$ dengan sirosis, sedangkan genotipe $\mathrm{B}$ lebih sering ditemukan pada penderita $\mathrm{KH}$ tanpa sirosis. Infeksi VHB dapat menyebabkan $\mathrm{KH}$ tanpa terjadinya sirosis terlebih dahulu, oleh karena VHB mempunyai kemampuan untuk mengintegrasikan DNA genomnya pada genom sel terinfeksi serta komponen HBx yang merupakan protein genotoksik, mampu memodifikasi ekspresi beberapa faktor pertumbuhan yang penting pada proses karsinogenesis. ${ }^{17}$ Untuk mengetahui lebih lanjut tentang pengaruh genotipe pada perjalanan penyakit hepatitis B kronik di Indonesia perlu dilakukan suatu penelitian prospektif. ${ }^{11}$

Hasil penelitian yang berbeda dilaporkan oleh tim peneliti dari Taiwan. Mereka melaporkan bahwa genotipe $\mathrm{C}$ lebih sering ditemukan pada penderita sirosis dan $\mathrm{KH}$ yang berusia di atas 50 tahun jika dibandingkan dengan populasi karier sehat, sedangkan genotipe B sering ditemukan pada penderita KH yang berusia muda. Selain itu, genotipe $\mathrm{C}$ berhubungan dengan tingkat positivitas $\mathrm{HBeAg}$ dan kadar DNA VHB yang lebih tinggi serta serokonversi dari $\mathrm{HBeAg}$ positif ke $\mathrm{HBe} A g$ negatif yang lebih rendah dibandingkan dengan genotipe B. ${ }^{6}$ Adanya perbedaan hasil dari berbagai penelitian yang dilakukan di berbagai negara semakin mengindikasikan bahwa pengaruh genotipe VHB pada manifestasi klinis hepatitis $\mathrm{B}$ tidak bersifat universal. Hal ini mungkin disebabkan masih banyaknya faktor variasi genetik VHB lainnya yang berkaitan dengan virulensi VHB, seperti adanya perbedaan distribusi subgenotipe, virus mutan dan single nucleotide polymorphisms (SNPs) yang spesifik, baik secara geografik maupun etnik. ${ }^{14}$

Perjalanan penyakit hepatitis B kronik dipengaruhi oleh faktor virus, pejamu, dan lingkungan. Selain genotipe VHB, faktor virus lainnya yang telah diketahui dapat mempengaruhi manifestasi klinis hepatitis B kronik adalah adanya virus mutan. Saat ini ada beberapa mutasi pada genom VHB yang telah diidentifikasi merupakan substitusi satu basa (G-A) pada nukleotida 1896 gen precore VHB yang menyebabkan pembentukan stop kodon, sehingga menghambat ekspresi HBeAg. Mutasi pada daerah precore ini sering ditemukan pada penderita hepatitis B kronik dengan $\mathrm{HBe} \mathrm{Ag}$ negatif dan telah dilaporkan berhubungan dengan terjadinya $\mathrm{KH}$ pada penderita hepatitis B kronik. ${ }^{18}$ Untuk memperoleh informasi lebih lanjut tentang pengaruh varian VHB pada perjalanan penyakit hepatitis B kronik perlu dilakukan penentuan frekuensi mutasi ini pada berbagai genotipe VHB. Sebagai informasi awal, penelitian yang dilakukan oleh peneliti pada tahun 2006 didapatkan mutan precore pada 93\% penderita hepatitis B kronik aktif dan $73 \%$ donor darah. ${ }^{19}$

Simpulan dari penelitian ini adalah terdapat dua genotipe VHB pada penderita hepatitis B kronik di Pekanbaru, yaitu genotipe B dan C, serta genotipe $\mathrm{C}$ merupakan genotipe yang dominan. Subtipe adr merupakan subtipe yang paling banyak ditemukan, diikuti oleh subtipe adw dan ayw. Tidak terdapat perbedaan distribusi genotipe dan subtipe VHB antara berbagai manifestasi klinis hepatitis B kronik. Genotipe C merupakan genotipe VHB yang paling banyak ditemukan pada penderita KH dengan sirosis, sedangkan genotipe B merupakan genotipe VHB yang paling banyak menginfeksi penderita $\mathrm{KH}$ tanpa sirosis. Genotipe VHB mungkin berhubungan dengan patogenesis karsinoma hepatoselular dengan sirosis dan tanpa sirosis.

\section{Ucapan Terima Kasih}

Penelitian ini dibiayai oleh Dana Hibah Bersaing Dikti 2009. Ucapan terima kasih disampaikan kepada pihak PMI Cabang Pekanbaru yang telah memberi kemudahan pada peneliti untuk memperoleh sampel penelitian, serta pihak lain yang tidak dapat disebutkan satu per satu dan telah membantu kelancaran penelitian ini.

\section{Daftar Pustaka}

1. Yang HI, Yeh SH, Chen PJ, Iloeje UH, Jen $\mathrm{CL}, \mathrm{Su}$ J, dkk. Associations between hepatitis $\mathrm{B}$ virus genotype and mutants and the risk of hepatocellular carcinoma. J Natl Cancer Inst. 2008;100(16):1134-43.

2. Nugrahaputra VE, Lusida MLI, Soetjipto, Mertaniasih NM. Hepatitis B virus genotypes 
and subtypes in blood donors with hepatitis $B$ surface antigen (HBsAg)-positive in Jayapura, Papua. Paper presented at: Seminar Nasional ke VII dan Kongres X PBBMI 2005; Pekanbaru.

3. Norder H, Courouce AM, Coursaget P, Echevarria JM, Lee SD, Mushahwar IK, dkk. Genetic diversity of hepatitis B virus strains derived worldwide: genotypes, subgenotypes, and HBsAg subtypes. Intervirology. 2004;47(6):289-309.

4. Arauz-Ruiz P, Norder $H$, Robertson BH, Magnius LO. Genotype H: a new Amerindian genotype of hepatitis B virus revealed in Central America. J Gen Virol. 2002;83(Pt 8):2059-73.

5. Stuyver L, De Gendt S, Van Geyt C, Zoulim F, Fried M, Schinazi RF, dkk. A new genotype of hepatitis B virus: complete genome and phylogenetic relatedness. J Gen Virol. 2000;81(Pt 1):67-74.

6. Kao JH. Hepatitis B virus genotypes and hepatocellular carcinoma in Taiwan. Intervirology. 2003;46(6):400-7.

7. Du H, Li T, Zhang HY, He ZP, Dong QM, Duan XZ, dkk. Correlation of hepatitis B virus (HBV) genotypes and mutations in basal core promoter/precore with clinical features of chronic HBV infection. Liver Int. 2007;27(2):240-6.

8. Yang HI, Yeh SH, Chen PJ, Iloeje UH, Jen $\mathrm{CL}, \mathrm{Su} \mathrm{J}$, dkk. Associations between hepatitis $B$ virus genotype and mutants and the risk of hepatocellular carcinoma. J Natl Cancer Inst. 2008;100(16):1134-43.

9. Yu MW, Yeh SH, Chen PJ, Liaw YF, Lin CL, Liu CJ, dkk. Hepatitis B virus genotype and DNA level and hepatocellular carcinoma: a prospective study in men. J Natl Cancer Inst. 2005;97(4):265-72.

10. Kao JH, Chen PJ, Lai MY, Chen DS. Hepatitis B genotypes correlate with clinical outcomes in patients with chronic hepatitis B. Gastroenterology. 2000;118(3):5544-9.

11. Utama A, Purwantomo S, Siburian MD, Dhenni R, Gani RA, Hasan I, dkk. Hepatitis $B$ virus subgenotypes and basal core promoter mutations in Indonesia. World J Gastroenterol.
2009;15(32):4028-36.

12. Zainal A, Arfianti, Ismawati. Genotypes and subtypes of hepatitis B virus among chronic hepatitis B patients in Pekanbaru, Indonesia. Jurnal Ilmu Kedokteran. 2007;1(1):1-3.

13. Mulyanto, Depamede SN, Surayah K, Tsuda F, Ichiyama K, Takahashi M, dkk. A nationwide molecular epidemiological study on hepatitis $B$ virus in Indonesia: identification of two novel subgenotypes, B8 and C7. Arch Virol. 2009;154(7):1047-59.

14. Nurainy N, Muljono DH, Sudoyo H, Marzuki S. Genetic study of hepatitis B virus in Indonesia reveals a new subgenotype of genotype B in East Nusa Tenggara. Arch Virol. 2008;153(6):1057-65.

15. Julius, Theja MD, Saptino M, Arnelis, Nasrul $\mathrm{Z}$, Sukowati CHC, dkk. Distribution of HBV serotype and genotype in West Sumatera: revisiting adr-zone in West Indonesia. Paper presented at: The First China-Indonesia Joint International Symposium on hepatobiliary medicine and surgery; August, 23rd-26th 2007 August; Bali, Indonesia.

16. Lusida MI, Surayah, Sakugawa H, NaganoFujii M, Soetjipto, Mulyanto, dkk. Genotype and subtype analyses of hepatitis $\mathrm{B}$ virus (HBV) and possible co-infection of HBV and hepatitis $\mathrm{C}$ virus (HCV) or hepatitis $\mathrm{D}$ virus (HDV) in blood donors, patients with chronic liver disease and patients on hemodialysis in Surabaya, Indonesia. Microbiol Immunol. 2003;47(12):969-75.

17. Trevisani F, Frigerio M, Santi V, Grignaschi A, Bernardi M. Hepatocellular carcinoma in non-cirrhotic liver: A reappraisal. Dig Liver Dis. 2010 Mei;42(5):341-7.

18. Tong MJ, Blatt LM, Kao JH, Cheng JT, Corey WG. Basal core promoter T1762/A1764 and precore A1896 gene mutations in hepatitis B surface antigen-positive hepatocellular carcinoma: a comparison with chronic carriers. Liver Int. 2007;27(10):1356-63.

19. Zainal A, Arfianti, Endriani R, Fidiawati WA. Frequency of precore mutant hepatitis $B$ virus and viremia status in chronic hepatitis B patients in Pekanbaru. Jurnal Natur Indonesia. 2006;9(1):7-10. 